4. Про зовнішньоекономічну діяльність : Закон України від 16 квітня 1991 р. № 959-ХII. URL: http://zakon.rada.gov.ua/laws/show/959-12.

5. Сільченко С.О. Строковий трудовий договір за законодавством України: поняття, види, умови укладення, зміни та припинення. Харків : Золоті сторінки, 2005. 203 с.

6. Лескова Л.Ф. Фріланс та його перспективи на українському ринку праці. Topical issues of science and education. 2017. № 3. C. 22-25.

7. Столярчук Н.Ю. Класифікація фрілансерів. Lviv Polytechnic National University Institutional Repository. 2012. № 2. C. 108-114.

УДК 349.3

DOI https://doi.org/10.32844/2618-1258.2019.5-1.13

БЕЗУСИЙ В.В.

\title{
МЕТОДИ СОЦІАЛЬНОГО ЗАХИСТУ ДЕРЖАВНИХ СЛУЖБОВЦІВ
}

\begin{abstract}
У статті проаналізовано специфіку методів соціального захисту державних службовців. Виділено такі види методів соціального захисту державних службовців: метод примусу, метод страхування, метод надання соціальної допомоги, метод державних компенсацій. Наголошено, що метод примусу дозволяє розкрити комплексність соціального захисту державних службовців, оскільки об'єднує правові норми різних галузей права та різні нормативно-правові акти. Дана норма завдяки застосуванню методу примусу здійснює соціальний захист державних службовців від безробіття, оскільки видання та здійснення злочинного наказу матиме як наслідок втрату посади та притягнення до юридичної відповідальності, а також гарантує безпечні для фізичного та психологічного здоров'я умови праці через зменшення стресу та надмірного тиску з боку безпосереднього керівника. 3'ясовано, що примус у соціальному захисті стосується не самих державних службовців, а осіб, що забезпечують їхні інтереси та від яких залежить якість такого захисту. Отже, необхідність у використанні примусу залежить від того виду соціальних ризиків, на виникнення яких державний службовець не впливає, однак які мають активний характер. Визначено, що методи соціального захисту державних службовців - це систематизоване об'єднання правових способів та засобів впливу уповноважених державою органів влади на суспільні відносини із соціального захисту державних службовців шляхом діяльності щодо реалізації норм права 3 метою зменшення ймовірності настання соціальних ризиків та їх негативних наслідків для державних службовців. Зроблено висновок, що компенсація має не лише матеріальний характер, як щодо оплати понаднормових годин роботи, але й фактичний - через використання годин та днів відпочинку у зручний для державного службовця час після усунення причин понаднормової роботи. Таким чином, метод компенсації використовується для забезпечення виконання обов'язків державного службовця як представника держави так як працівника, а також для захисту його соціальних інтересів та членів його сім'ї в питаннях сімейного і матеріального добробуту.

Ключові слова: метод, сочіальний захист, державні службовиі, сочіальне законодавство, сочіальне забезпечення.
\end{abstract}

The article analyzes the specifics of methods of social protection of civil servants. The following types of methods of social protection of civil servants are distinguished: method of coercion, method of insurance, method of providing social assistance, method

(C) БЕЗУСИЙ В.В. - кандидат юридичних наук, доцент, професор кафедри правового забезпечення господарської діяльності факультету № 6 (Харківський національний університет внутрішніх справ) 
of state compensations. It is emphasized that the method of coercion allows to reveal the complexity of social protection of civil servants, as it combines the legal norms of different branches of law and different regulations. Due to the use of coercion, this norm provides social protection of civil servants from unemployment, as the issuance and execution of a criminal order will result in the loss of position and prosecution, as well as provide safe working conditions for physical and psychological health by reducing stress and excessive pressure. by the immediate supervisor. It has been found that coercion in social protection does not concern civil servants themselves, but those who protect their interests and on whom the proper quality of such protection depends. Thus, the need to use coercion depends on the type of social risks that are not affected by the civil servant, but which are active. It is determined that the methods of social protection of civil servants is a systematic combination of legal methods and means of influencing the state authorities on public relations for social protection of civil servants through the implementation of legal norms to reduce the likelihood of social risks and their negative consequences for public employees. It is concluded that the compensation is not only material in nature, as for the payment of overtime, but also actual due to the use of hours and days of rest at a convenient time for a civil servant after eliminating the causes of overtime. Thus, the method of compensation is used both to ensure the performance of the duties of a civil servant, both a representative of the state and as an employee, as well as to protect his social interests and family members in relation to family and material well-being.

Key words: method, social protection, civil servants, social legislation, social security.

Вступ. Методи соціального захисту дозволяють відтворити особливості соціального захисту шляхом визначення меж втручання держави в суспільні відносини, а також визначають основну мету такого втручання. Відповідно, дане дослідження дозволить визначити, які саме методи використовуються в соціальному захисті державних службовців, а також їхню специфіку. Крім того, саме дане дослідження допоможе віднайти вірну класифікацію методів, яка дозволить впливати на суспільні відносини комплексно та підвищувати рівень соціального захисту державних службовців.

Методи соціального захисту визначають і систему відповідних засобів. Саме засоби дозволяють розглянути здійснюваний вплив більш деталізовано та визначити, чи $є$ його рівень достатнім. Також саме завдяки аналізу засобів соціального захисту можливо проаналізувати норму права щодо можливостей іiі реалізації, вірного закріплення в законодавчому приписі, який би не дозволяв подвійного тлумачення та виникнення колізій. Дослідження засобів соціального захисту надасть можливість краще зрозуміти їхні особливості, що вплине і на практичне їх застосування через обрання більш доцільного та дієвого виду соціального захисту. Засоби соціального захисту мають науково-теоретичне значення, що дозволяє їх виокремити в системі та механізмі соціального захисту державних службовців.

Стан дослідження. Питання методів соціального захисту державних службовців поки що не мало достатнього наукового дослідження, однак окремими фундаментальними аспектами займались такі вчені: В.Б. Авер'янов, В.С. Андріїв, Ю.П. Битяк, Н.Б. Болотіна, І.П. Греков, С.Д. Дубенко, М.Л. Захаров, М.І. Іншин, Г.І. Леліков, В.Я. Малиновський, О.Є. Мачульська, О.Ю. Оболенський, І.М. Пахомов, П.Д. Пилипенко, С.М. Прилипко, А.В. Сапон, С.М. Синчук, Б.І. Сташків, I.C. Ярошенко, Є.С. Черноног та інші.

Результати дослідження. I метою більш глибокого розуміння даного правового явища насамперед слід виділити його поняття. Так, у Сучасному словнику української мови метод тлумачать як спосіб пізнання явищ природи та суспільного життя; прийом або систему прийомів, що застосовуються в якій-небудь галузі діяльності [1]. Тобто метод ототожнюється із способом або їх сукупністю, однак жоден із таких підходів не $є$ вірним. Спосіб визначає, яким чином буде здійснюватися вплив на певні суспільні відносини, однак саме метод визначатиме послідовність, тривалість та необхідність у застосуванні того чи іншого способу. Тобто, дійсно, спосіб є одним із елементів методу. Разом із тим метод не може бути сукупністю способів, оскільки саме метод має бути структурним, забезпечувати стабільність і надавати можливість прогнозування результату впливу. Відповідно, використання загально визначення не має наукової цінності в межах даного дослідження. 
Більш точне визначення в межах права надає Ю.С. Шемшученко, який під методом правового регулювання розуміє спосіб впливу юридичної норми на суспільні відносини [2, с. 617]. Важливим у даному випадку є виділення саме ролі норм права, адже саме аналіз норми права та їх сукупності дозволяє виділяти різні методи, а також зрозуміти їх призначення. Однак можливо й визначити обернений зв'язок, коли норма права формується виходячи з обгрунтованості метода, а отже, й визначення, надане автором, висвітлює лише один бік явища. Крім того, в межах соціального захисту методи повинні відображати відносини між державою та споживачем державних послуг щодо захисту, якими є державні службовці. Відповідно, законодавчі приписи формуються виходячи саме 3 даних положень, тобто первинним є саме метод.

Тож метод визначає, як саме регулюватимуться відносини щодо соціального захисту. Щодо сутності таких методів, то М.В. Цвік визначає, що те чи інше сполучення основних і допоміжних способів правового регулювання, наявність (чи відсутність) можливості в осіб, на яких воно поширюється, самостійно встановлювати та уточнювати правові форми їх поведінки, характер підстав, із настанням яких пов'язуються виникнення, зміна та припинення правових стосунків між ними, а також ступінь деталізованості правового регулювання дають уявлення про методи правового регулювання суспільних відносин [3, с. 215]. Тобто в межах соціального захисту державних службовців, методи визначають характер діяльності щодо захисту, визначають роль кожного із суб'єктів та межі їх повноважень. Саме за допомогою методів відбувається зміна правовідносин, як щодо їх початку, так й щодо завершення. Наприклад, соціальний захист шляхом визначення тривалості робочого дня для державних службовців має імперативний характер, оскільки є обов'язковим для всіх, а також і таким, що постійно триває. Однак якщо мова йде про державну компенсацію, методи соціального захисту будуть спрямовані саме на завершення відносин шляхом виплати відшкодування.

Вірно вказує В.Д. Сорокін, що основний методологічний прийом полягає в тому, що під час визначення поняття методу правового регулювання загалом, а також під час конструювання методів різних галузей права використовуються виключно дві «цеглинки»- цивільний та адміністративний методи. Саме на їх основі, на співвідношенні методів цивільного та адміністративного права багато авторів зводять конструкцію методу «своєї» галузі [4, с. 40-41]. Такий підхід дозволяє знайти баланс щодо ролі держави в соціальному захисті та межах втручання у виконання обов'язків державними службовцями. Разом із тим методи соціального захисту містять не лише виключно правові способи, але й економічні та екологічні. Відповідно, сутність методів соціального захисту повинна відображати як правовий характер, так і зв'язок із іншими сферами. Надання соціальної допомоги повинно розрізнятись залежно від матеріального стану, можливостей використати пільги та необхідності в отриманні такої допомоги.

Дещо більш широкий підхід використовує Є.О. Харитонов та вказує, що метод правового регулювання - системне комплексне застосування методів цивільного, адміністративного і кримінального права (що визначає міжгалузеву сутність публічно-правового регулювання) з урахуванням методів приватноправового регулювання (на рівні угод, добрих звичаїв, традицій, норм суспільної моралі, ділової етики) [5]. Дійсно, соціальний захист державних службовців неможливо включити лише до однієї галузі та використовувати ії метод, оскільки соціальний захист охоплює широкий комплекс суспільних відноси. Однак даний підхід не дозволяє стверджувати про самостійність та особливість методів соціального захисту, оскільки тлумачить їх лише як певним чином угруповане зібрання методів із інших галузей права. Ураховуючи й сутність діяльності державних службовців та їхній зв'язок із трудовою сферою та публічним адмініструванням, стає зрозумілим, що методи соціального захисту повинні відображати специфіку, бути пристосованими до видів суспільних відносин, що виникають у процесі такого захисту, а отже, отримане поєднання матиме унікальний характер.

Таким чином, проаналізувавши основні наукові підходи та враховуючи проведені дослідження, можна дійти висновку, що методи соціального захисту державних службовців - це систематизоване об'єднання правових способів та засобів впливу уповноважених державою органів влади на суспільні відносини із соціального захисту державних службовців шляхом діяльності щодо реалізації норм права з метою зменшення ймовірності настання соціальних ризиків та їх негативних наслідків для державних службовців.

Досліджуючи класифікацію методів, слід враховувати й елементи методу, на які звертає увагу Р.Я. Демків: способи взаємозв'язку прав і обов'язків між учасниками врегульованих правовідносин; сукупність юридичних фактів, які є підставою виникнення, зміни чи припинення правовідносин; санкції, способи і процедури їх застосування [6, с. 22]. Перші два елементи мо- 
жуть застосовуватись щодо різних методів соціального захисту, однак останній елемент дозволяє виділити такий метод захисту, як примус. Саме завдяки застосуванню методу примусу можливо притягнути до юридичної відповідальності у випадках невиконання повноважень щодо соціального захисту або ж відновити порушене право. Крім того, метод примусу дозволяє об'єднати різні види санкцій шляхом указання єдиної мети.

A.I. Якимів виділяє напрями здійснення соціального захисту в Україні, якими є забезпечення допомоги і страхування [7, с. 223]. Дані напрями слід враховувати, оскільки вони дозволяють зрозуміти, у яких сферах використовуються методи соціального захисту, а отже, краще відтворити їх сутність та визначити, чи належним чином вони відображені в національному законодавстві. Слід вказати, що методи соціального захисту мають більш загальний характер, а отже, стосовно державної служби будуть існувати виключення щодо певних відносин. Наприклад, соціальне страхування, розмір пенсії та тривалість відпустки будуть різнитись залежно від виду діяльності державного службовця.

Тож можна виділити такі види методів соціального захисту державних службовців:

1. Метод примусу.

2. Метод страхування.

3. Метод надання соціальної допомоги.

4. Метод державних компенсацій.

Метод примусу має імперативний характер та відображає зв'язок соціального захисту та державної служби 3 державою владою та адміністративним правом. Із даного питання М.В. Ковалів визначає, що адміністративний примус $\epsilon$ засобом вольового забезпечення відповідності правовій нормі поведінки громадян, посадових та юридичних осіб за допомогою заходів впливу, врегульованих адміністративно-правовими нормами, з метою досягнення відповідного порядку, припинення та попередження правопорушень, притягнення до відповідальності правопорушників [8, с. 215]. Тобто в межах соціального захисту державних службовців метод примусу може застосовуватись не лише щодо притягнення до відповідальності - до нього можна віднести обов'язок дотримуватися тих норм, що забезпечують реалізацію соціального захисту. Варто наголосити, що обов'язковим елементами примусу в соціальному захисті $є$ його правовий характер, оскільки саме він відрізнятиме правомірні дії. Правовий характер дозволить діяти в тих межах, що не встановлюють нові привілеї та переваги для державних службовців шляхом застосування сили. Крім того, до особливостей примусу в соціальному захисті державних службовців слід віднести вольовий характер, оскільки примус, на відміну від інших методів, зокрема соціальна допомога чи страхування, не може застосовуватись автоматично, без попереднього дослідження умов та підстав. Відповідно, правові норми, у яких використовується метод примусу, стосуються діяльності державних службовців не лише як працівників, але і як представників держави.

Відповідно до п. 9 ст. 9 Закону України «Про державну службу» за видання керівником та виконання державним службовцем явно злочинного наказу (розпорядження), доручення відповідні особи несуть відповідальність згідно із законом [9]. У даній правовій нормі метод примусу визначається як через застосування способу заборони на видання злочинних наказів, так i шляхом встановлення санкції за ії порушення. Також саме метод примусу дозволяє розкрити комплексність соціального захисту державних службовців, оскільки об'єднує правові норми різних галузей права та різні нормативно-правові акти. Дана норма завдяки застосуванню методу примусу здійснює соціальний захист державних службовців від безробіття, оскільки видання та здійснення злочинного наказу матиме як наслідок втрату посади та притягнення до юридичної відповідальності, а також забезпечує безпечні для фізичного та психологічного здоров'я умови праці через зменшення стресу та надмірного тиску з боку безпосереднього керівника.

Згідно зі ст. 55 Закону України «Про загальнообов'язкове державне пенсійне страхування» в разі безпідставної відмови в наданні розпорядження зберігачу щодо перерахування коштів для оплати договору страхування довічної пенсії територіальний орган Пенсійного фонду несе відповідальність згідно із законом [10]. Таким чином, примус у соціальному захисті стосується не самих державних службовців, а осіб, що забезпечують їхні інтереси та від яких залежить належна якість такого захисту. Отже, необхідність у використанні примусу залежить від того виду соціальних ризиків, на виникнення яких державний службовець не впливає, однак які мають активний характер. Так, якщо пенсійне забезпечення викликане настанням соціального ризику об’єктивного характеру, а саме досягненням державним службовцем пенсійного віку, то відмова від такого забезпечення матиме обов'язково усвідомлений та протиправний характер, а отже, потребує застосування методу примусу та відповідних засобів. 
Наступний метод соціального захисту державних службовців відрізняється значною диференціацією, а також розкриває зв'язок соціального захисту з економічним станом у державі. Так, саме метод страхування спрямований на встановлення стабільності й передбачуваності стану матеріального забезпечення державного службовця. С.Д. Нечипоренко звертає увагу, що матеріальне забезпечення працівників, що здійснюється в рамках соціального страхування, сприяє підтримці певного рівня життя громадян і їхніх сімей у разі настання страхових випадків, а також дозволяє особам, що втратили працездатність, відновлювати іiі [9, с. 59]. Значна частина сфер державної служби пов'язана з можливим ризиками для здоров'я, тому метод страхування спрямований не лише на забезпечення наявності коштів на відповідне лікування, але і на захист членів сім'ї або ж осіб, за якими доглядає державний службовець шляхом встановлення звичайного рівня матеріального достатку. Однак слід вказати, що страхування, хоча і завжди потребує економічних ресурсів, у соціальному захисті державних службовців має декілька різних цілей. Так, відповідно до ст. 90 Закону України «Про державну службу» визначено, що пенсійне забезпечення здійснюється в порядку, визначену Законом України «Про загальнообов'язкове державне пенсійне страхування» [11]. Таким чином, у даному випадку метод страхування спрямований на допомогу в реалізації права особи на відпочинок, на матеріальне забезпечення, на належні умови життя. Разом із тим метод страхування може бути використаний лише в певних видах державної служби. Так, відповідно до ч. 2 ст. 34 Закону України «Про дипломатичну службу» за рахунок державних коштів відшкодовуються витрати дипломатичної служби, пов'язані $з$ наданням медичної допомоги або медичним страхуванням, що забезпечують необхідний обсяг екстреної, первинної та вторинної (спеціалізованої) медичної допомоги на території держави акредитації та/або держав зони відповідальності закордонної дипломатичної установи України [12]. Відповідно, страхування використовується задля забезпечення права на життя та здоров'я осіб і створення належних умов реалізації таких прав. Відмінністю даного виду методу страхування є джерело надходження коштів, яким є саме держава, коли в першому випадку внески здійснюються за рахунок коштів самого державного службовця. Слід вказати, що метод страхування сьогодні має незначне поширення саме щодо державних службовців, однак саме його використання заохочуватиме працювати в державній службі, оскільки визначатиме спланованість і забезпеченість майбутнього від соціальних ризиків. Проте законодавство потребує значного вдосконалення щодо спеціальних видів страхування залежно від сфери державної служби.

Метод надання соціальної допомоги є одним із найбільш типових для соціального захисту державних службовців, оскільки підставами для його застосування є побутові ситуації. Так, відповідно до ст. 1-2 Порядку надання державним службовцям матеріальної допомоги для вирішення соціально-побутових питань державним службовцям матеріальна допомога може надаватися один раз на рік у розмірі середньомісячної заробітної плати на підставі особистої заяви для вирішення соціально-побутових питань [13]. Використання методу соціальної допомоги спрямоване на забезпечення можливості державним службовцем виконувати свої обов'язки через вирішення позапрофесійних проблем, які можуть впливати на якість і швидкість надання державних послуг. Аналізуючи даний Порядок, розуміємо, що не використано всі можливості методу соціальної допомоги. Насамперед, незрозуміло, чому ж обрана саме сума в розмірі середньомісячної заробітної плати, оскільки соціально-побутові питання можуть мати різний характер, а отже, більш доцільною була б диференціація можливих сум. Відповідно, більш детального тлумачення потребує термін «соціально-побутові питання» як щодо переліку, так і щодо дефініції. Крім того, не визначена відповідальність за нерозгляд заяви державного службовця та критерії обгрунтування необхідності в такій допомозі, що негативно впливає на ефективність методу. Соціальний захист повинен бути комплексним, а отже, й використання методу соціальної допомоги повинно бути поєднаним із методом примусу.

Соціальна допомога як метод соціального захисту повинна бути спрямована і на членів сім’ї державного службовця. Саме тому ст. 36 Закону України «Про дипломатичну службу» визначає, що в разі загибелі (смерті) за кордоном працівника дипломатичної служби, направленого в довготермінове відрядження або службове відрядження, здійснюється оплата послуг із репатріації останків за адресою реєстрації загиблого (померлого) за рахунок кошторису відповідної закордонної дипломатичної установи України [12]. Оплата послуг із репатріації дозволяє зменшити витрати членів сім'ї, а отже, й забезпечити більш тривале їх стабільне матеріальне становище. Важливим є відокремлення методу соціальної допомог від методу компенсації, оскільки останній використовується у випадках відшкодування певної шкоди або ж витрат під час виконання безпосередніх функцій держави. Відповідно, такі методи можуть застосовуватись у сукупності 
щодо захисту інтересів державних службовців та членів їхніх сімей у випадку настання нещасних випадків. Проте на науково-теоретичному рівні їх розподіл сприятиме зменшенню невірного розуміння призначення норм права та більш детальному дослідженню їхніх меж.

Підстави для використання методу державних компенсацій під час здійснення дипломатичної служби розкриті в законодавстві, а їх деталізація здійснюється в ч. 1 ст. 4 Постанови Кабінету Міністрів України «Про упорядкування здійснення компенсаційних виплат в іноземній валюті та оплати інших витрат працівникам дипломатичної служби України, направленим у довготермінове відрядження», де вказано, що компенсується вартість проїзду до місця призначення; вартість користування постільними речами в поїздах; вартість обов'язкового щеплення відповідно до вимог Всесвітньої організації охорони здоров'я; вартість наймання житлового приміщення в тому числі бронювання переїздом в Україну з метою перебування у відпустці та повернення 3 неї один раз у поточному календарному році [14]. Тобто метод компенсації стосується як використання соціально-побутових послуг, так і відновлення здоров'я та реалізації права на відпочинок. Перебування в іншій державі для дипломатичного службовця може мати негативні наслідки у вигляді непередбачуваних витрат через інші ціни та особливості надання послуг в іноземній державі, відповідно, саме метод компенсації спрямований на встановлення очікуваного рівня витрат і незмінності планів розвитку такого державного службовця.

Висновки. У визначених законом випадках державний службовець повинен виконувати свої обов'язки незалежно від тривалості робочого дня. А отже, ч. 4 ст. 56 Закону України «Про державну службу» визначено, що за роботу в зазначені дні (час) державним службовцям надається грошова компенсація в розмірі та порядку, визначених законодавством про працю, або протягом місяця надаються відповідні дні відпочинку за заявами державних службовців [9]. Тобто компенсація має не лише матеріальний характер, як щодо оплати понаднормових годин роботи, але й фактичний - через використання годин та днів відпочинку у зручний для державного службовця час після усунення причин понаднормової роботи. Таким чином, метод компенсації використовується для забезпечення виконання обов'язків державного службовця як представника держави так як працівника, а також для захисту його соціальних інтересів та членів його сім'ї в питаннях сімейного й матеріального добробуту.

Тож на основі аналізу методів соціального захисту державних службовців можемо виділити їхні ознаки як цілісної та взаємодоповнюючої системи:

1. Соціально-економічна спрямованість.

2. Перманентність застосування.

3. Необхідність у деталізації механізму втілення.

\section{Список використаних джерел:}

1. Академія наук України. Словник української мови у 20 томах. URL : https://bitly.su/ 7WmpvLJz (дата звернення: 27.09. 2019)

2. Шемшученко Ю.С. Юридична енциклопедія. Київ : Вид.во «Українська енциклопедія» імені М.П. Бажана, 2001. 789 с. $2011.584 \mathrm{c}$.

3. Цвік М.В., Петришин О.В. Загальна теорія держави і права. Харків : «Право»,

4. Сорокін В.Д. Метод правового регулювання. Теоретичні проблеми. Москва : Юридическая литература,1976. 144 с.

5. Харитонов С.О., Харитонова О.I. Юридична сутність «IT-права». URL : https://bitly.su/ 5sKVK0 (Дата звернення: 27.09.2019).

6. Демків Р.Я. Правове регулювання як юридичне явище: окремі аспекти розуміння. Науковий вісник Ужгородського начіонального університету. Серія : Право. 2015. Вип. 34(1). C. 19-23.

7. Якимів А.І. Формування і розвиток системи пенсійного забезпечення в Україні. Львів : Афіша, 2003. 448 с

8. Ковалів М.В. Переконання та примус як загальні методи впливу в органах виконавчої влади. Науковий вісник Львівського держсвного університету внутрішніх справ. серія юридична. 2015. № 1. C. 211-219.

9. Про державну службу : Закон України від 10.12.2015 № 889-VIII. Відомості Верховної Ради Украӥни (ВВР). 2016. № 4. С. 43.

10. Про загальнообов'язкове державне пенсійне страхування : Закон України від 09.07.2003 № 1058-IV. Відомості Верховної Ради Украӥни (ВВР). 2003. № 49. С. 376. 
11. Нечипоренко С.Д. Сутність та значення соціального страхування в системі соціального захисту населення. Агросвіт. 2017. № 6. С. 55-60.

12. Про дипломатичну службу : Закон України від 07.06.2018 № 2449-VIII. Вiдомості Bepховної Ради України (ВВР). 2018. № 50. С. 7.

13. Про затвердження Порядку надання державним службовцям матеріальної допомоги для вирішення соціально-побутових питань : Постанова Кабінету Міністрів України від 08.08.2016 № 500. Офічіийний вісник України. 2016. № 65. С. 44.

14. Про упорядкування здійснення компенсаційних виплат в іноземній валюті та оплати інших витрат працівникам дипломатичної служби України, направленим у довготермінове відрядження : Постанова Кабінету Міністрів України від 17.04.2019 № 332. Офіиійний вісник України . 2019. № 34. C. 284.

УДК 349.3

DOI https://doi.org/10.32844/2618-1258.2019.5-1.14

ВІЖУНОВ О.В.

\title{
ДОКТРИНАЛЬНІ ПІДХОДИ ДО РОЗУМІННЯ ПОНЯТТЯ «ОСОБА 3 ІНВАЛІДНІСТЮ»
}

\begin{abstract}
У статті досліджуються основні теоретико-правові підходи до розуміння «особа 3 інвалідністю». Основна увага приділяється питанням щодо поняття соціального захисту осіб з інвалідністю. Розкриваються науково-теоретичні підходи. Аналізуються і досліджуються положення чинного законодавства про права осіб з інвалідністю. 3'ясовано, що Всесвітня організація охорони здоров'я рекомендує розглядати інвалідність як біосоціальну категорію, і проблеми інвалідності повинні розв'язуватися з біологічної, особистісної та соціальної позицій. Визначено, що людина з інвалідністю - це індивід, який має уроджені чи набуті приховані чи характерні ознаки розладу здоров'я, які обмежують життєдіяльність людини, що призводить до соціального захисту для повноцінного функціонування в суспільстві. Констатовано наявність великої кількості понять, які аналогічні терміну «інвалід», за допомогою якого визначається характеристика стану людини, ії відносять до особливої групи суспільства, що потребує сторонньої допомоги з його боку та боку оточуючих, оскільки самостійно не може себе обслуговувати та повноцінно жити. Зроблено висновок, що протягом останніх десятиліть у визначення поняття «інвалідність» вкладався різний зміст. На початку воно означало функціональне порушення органів чуття або фізичні недоліки, згодом трансформувавшись у несприятливе становище, опинившись у якому, людина з інвалідністю потребує підтримки. Так, інвалідність $є$ соціальним ризиком, що в контексті права соціального забезпечення означає становище людини, на подолання або зниження негативного впливу якого спрямований соціальний захист. Термін «людина 3 інвалідністю» включає у себе низку аспектів: а) наявність у людини певних медико-біологічних або психологічних обмежень, які негативно впливають на неї, ускладнюючи можливість повноцінного виконання широкого кола соціальних функцій, зокрема і комунікацію з оточуючими; б) специфічний правовий статус, який визначається законодавчими актами та додатковими документами, виданими людині індивідуально для підтвердження іiї статусу; в) сформоване під тиском та впливом історичних та етнічних особливостей ставлення до неї з боку оточення та соціуму в цілому.

Ключові слова: сочіальний захист, сочіальне забезпечення, види сочіального забезпечення, соиіальні ризики, особи з інвалідністю, право на сочіальне забезпечення, законодавство про права осіб з інвалідністю.
\end{abstract}

(C) ВІЖУНОВ О.В. - здобувач кафедри правознавства (Східноукраїнський національний університет імені Володимира Даля) 